\title{
Reproductive and Lactation Performance of Crossbreed Dairy Cows in Bishoftu, Ada'a Distict of East Shoa, Eastern Ethiopia
}

\author{
Zelalem Abera $^{1^{*}}$, Biniam Mengiste $^{1}$ and Tilaye Demise ${ }^{2}$ \\ ${ }^{1}$ School of Veterinary Medicine,College of Medical and Health Sciences, Wollega University, \\ P.O. Box 395, Nekemte, Ethiopia \\ ${ }^{2}$ Ethiopian Meat and Dairy Technology Institute (EMDTI), Bishoftu, Ethiopia
}

\begin{tabular}{|c|c|}
\hline Abstract & Article Information \\
\hline 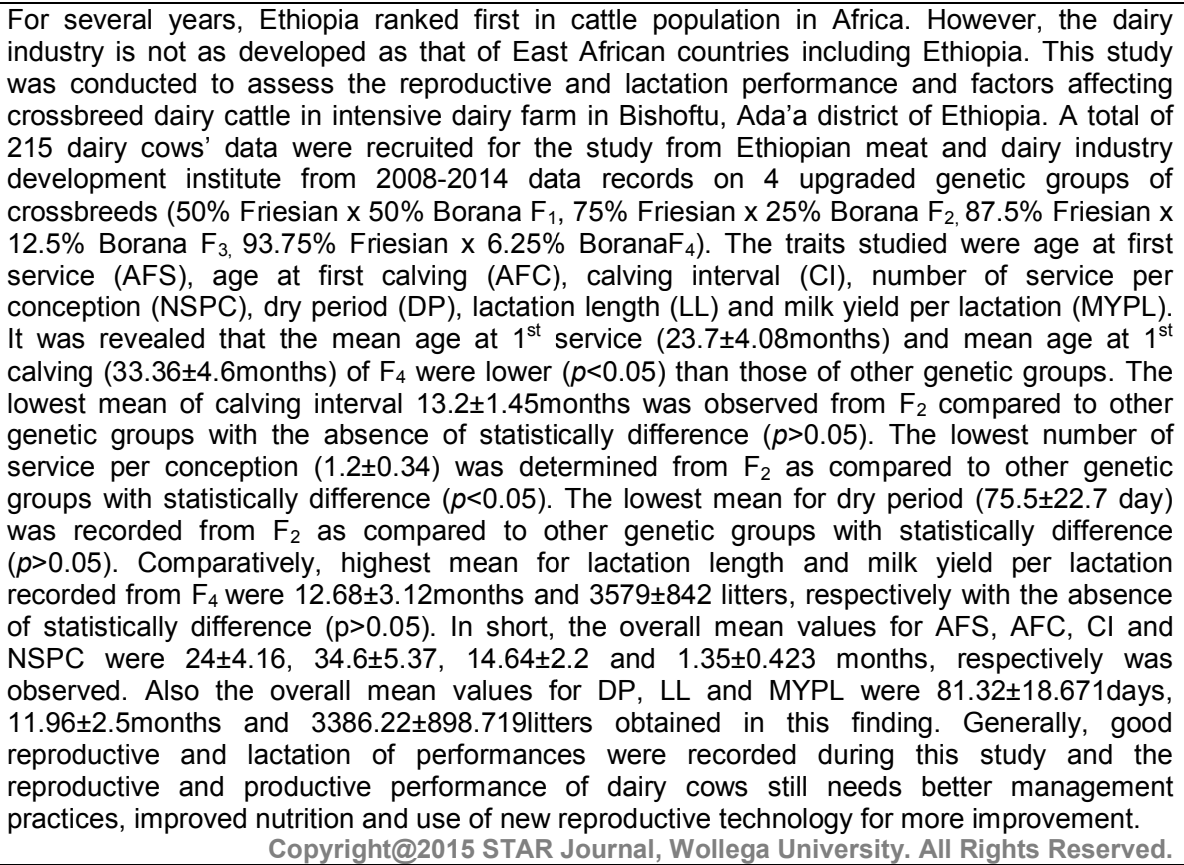 & $\begin{array}{l}\text { Cross breed } \\
\text { Genetic level } \\
\text { Performance } \\
\text { Production } \\
\text { Reproduction } \\
\text { 'Corresponding Author: } \\
\text { Zelalem Abera } \\
\text { E-mail: } \\
\text { besha.ab9@gmail.com }\end{array}$ \\
\hline
\end{tabular}

\section{INTRODUCTION}

Livestock contributes a direct role in generating food and income (Perry et al. 2003, Bonnet et al. 2011), livestock are a valuable asset, serving as a store of wealth, collateral for credit and an essential safety net during times of crisis throughout the developing world (Upton, 2001; MoA, 2006; FAO, 2009 and Forman et al., 2009) and generally generate a livelihood for 1.0 billion poor people in the world (Naqvi and Sejian, 2011).

A demand for livestock products in sub-Saharan Africa, and in developing countries in general, is likely to rise considerably as a result of rapidly growing human population, urbanization and income. This increase in demand for livestock products will have profound implications for food security, poverty alleviation, and the environment (Ehui, 2000).
In tropical country, the indigenous Zebu cattle are more adapted to the local tropical environment. However, their capacity for milk production is usually low. Selection for high milk production within indigenous cattle would require a long-term genetic improvement program. However, in the highland areas of the tropics with an annual rainfall above $1000 \mathrm{~mm}$, dairy is being carried out with relative success using imported and now adapted Boss taurus breeds, as well as their crosses with the Zebu. But there is a concern about reproductive performance of imported breeds and their high grade crosses under tropical condition (Kumar, et al., 1991).

Ethiopia is the largest country by having cattle population in Africa. This plays an important socioeconomic role by generating additional cash income and religious and cultural value. Due to this effect, almost all 
Zelalem Abera et al.,

rural and many peri-urban people keep small herd grazing cattle. In Ethiopia the livestock population was estimated about 22 million goats, 25 million sheep and 52.13 million heads of cattle which contributes $40 \%$ to the annual agricultural output and $215 \%$ total gross domestic product. Such cattle population produced a total of 1.5 million tons of milk and 0.331 million tons of meat annually (CSA, 2012).

Although, the livestock sector has a significant contribution to the national economy by resistance to drought, disease, parasite, poor quality feed and local environment production per animal is extremely poor. Whereas disease, drought or shortage of feed, scarcity of water, climatic constraints, poor market structure, wasteful production practice, inappropriate breed usage (local breed) are other different constraints (Damron, 2006).

Therefore they are under estimated, neglected and little attention was given to put them from research and developmental agenda. The average lactation milk productions of the indigenous cows were ranged from 494 to $850 \mathrm{~kg}$ under optimum management level. This indicated that the performance of the local breeds was poor when comparing to cross and exotic breeds. To meet the ever-increasing demand for milk, milk products and their contribution to economic growth, genetic improvement through crossing of the indigenous cattle has been proposed as one of the options (Aynalem et al., 2009).

Genetic improvement of the indigenous cattle, basically focusing on crossbreeding has been practiced for the last five decades (CSA, 2012). However, fertility rate of high grade and pure breed exotic dairy cattle suffered from poor reproduction performance, poor conception rate, long post partum anestrous and calving interval (Kiwuwa et al., 1983; Madalena et al., 1990). Therefore, an introduction of artificial insemination into dairy cattle in Ethiopia allowed for genetic improvement of local breed through crossbreeding specially in urban and peri-urban areas. These lower reproductive performances could be related to genetic, environment and management factor (Zegeye, 2003).

Even though little information available about the effect on reproductive and lactation performance of crossbreed dairy cattle at research and ranch condition, still it needs attention. Since Ada'a district is one which has enough intensive dairy management system in Ethiopia though ample studies have not been conducted on reproductive and lactation performance in intensive dairy farms. Therefore, objectives of this study were to determine the reproductive and milk production performance and factors affecting of crossbreed cows reared under intensive dairy production system in Ada'a district on Ethiopian Meat and Dairy Industry Development Institute (EMDIDI).

\section{MATERIALS AND METHODS}

\section{Description of Study Area}

This study was conducted in Ada'a district Debre Zeit town which is located $47 \mathrm{~km}$ south east of Addis Ababa, Ethiopia. The town lies between $9^{\circ} \mathrm{N}$ latitude up to $40^{\circ} \mathrm{E}$ longitudes and has an altitude of $1950 \mathrm{~m}-1900 \mathrm{~m}$. The area is characterized by mild subtropical with the minimum and maximum temperature ranging from $2-9^{\circ} \mathrm{C}$ and $20-27^{\circ} \mathrm{C}$, respectively. The rainfall is bimodal with an annual rainfall of $875 \mathrm{~mm}-1151.6 \mathrm{~mm}$ of which $84 \%$ is
Sci. Technol. Arts Res. J., Oct-Dec 2015, 4(4): 113-119

during the long rainy season covering June to September and the remaining in the short rainy season. About 180 ha $(86 \%)$ of the total land area is arable.

The Debre Zeit Research Station was established in 1975 under an agreement reached between the International Livestock Centre for Africa (ILCA) and the Government of Ethiopia. The Station, situated at the foothills of the Yerer Mountain, has a 210 hectare land granted from the Government of Ethiopia and is located at the outskirts of the Bishoftu town, about $50 \mathrm{~km}$ south-east of Addis Ababa, an hour drive from the Capital. The site has a panoramic view of the Yerer Mountain and borders with the Babo-Gaya Lake on the eastern side, one of the seven creator lakes in Bishoftu.

The main purpose of the Station was for ILCA to use it for livestock and livestock related research and capacity building activities. In 1995, the former ILCA with its Head Quarters in Addis Ababa and it's sister institution the former International Laboratory for Research on Animal Diseases (ILRAD) were merged to form one institution, the International Livestock Research Institute (ILRI) and all the property and resources of the Station were transferred to ILRI which continued to operate with more or less the same objectives. The location of the Station avails itself to easy access to diverse agro-ecologies and agricultural production systems. In January 2008 ILRI Station has been hand over to the Government and become Ethiopian Meat and Dairy Technology Institute (EMDTI).

\section{Study Design}

Retrospective study was conducted from 2008-2014 recorded data.

\section{Method of Data Collection}

Data for this study was extracted from the Ethiopian Meat and Dairy Industry Development Institute (EMDIDI). Data collected from 2008-2014 recorded data of birth date, calving dates, dates of first and subsequent artificial insemination, genetic level, lactation length, milk yield and health record. From collected information the following dependent variables of interest were derived; age at first service, age at first calving, calving intervals, number of service per consumption, dry period, lactation length and milk yield per lactation. Cows that exit the herd due to voluntary culling such as reduced milk production, older age and involuntary culling such as accidents or health cases were considered. In either case, only cows that completed at least age at first calving were included. The data were not censored and we used actual data sets that were collected over the entire lifetime of crossbred dairy cows.

\section{Herd Description and Animal Management}

Artificial insemination is the only breeding method for this dairy farm. The semen was purchased from Ethiopian National Artificial Insemination Center and Borona animals are inseminated with pure Fresian semen. The heifers were inseminated at 18 to 24 months of age and weighed $250 \mathrm{~kg}$ and above. After calving, The calves were then separated from their dams and kept in isolated individual calf pens in the cowshed then they were subjected to bottle-feeding with maternal colostrums and fresh warmed milk until weaning at 16 weeks (about 4 months or 112 days, and from 65 to $120 \mathrm{~kg}$ of body weight). 
Zelalem Abera et al.,

During that period they were bucket-fed whole milk warmed at $38^{\circ} \mathrm{C}$ twice daily (morning and evening) between 6-7 $\mathrm{h}$, and 16-17 $\mathrm{h}$. The litter, usually made of hay (dried grass) was changed regularly to limit infections. Water was given ad lib. Regular diets made of concentrate and cut grass were provided. Weaned calves at 16 weeks were sent to feedlot barn were they formed with heifers according to their age. The management pattern was semi-intensive. During the rainy season animals were put on natural pastures. In the dry season, they were mainly fed silage, together with hay. Milking was essentially performed with hand milking twice a day, at $4 \mathrm{~h}$ and $9 \mathrm{~h}$. During milking and immediately after, cows received a concentrate diet. Routine work consisted in attributing identification numbers to calves, and data recording for; calf birth date, birth weight, sex, calving season, dam age at calving, parity, monthly weighing, dehorning, milk yields, dry period, date and reason for culling. Vaccinations for bacterial and viral disease, prophylaxis against ectoparasites and indoparasite was regularly sprayed and dewormed.

\section{Data Handling and Analysis}

Data entry and management was made using Microsoft Excel sheets. Data analysis was made using Statistical Package for Social Science (SPSS) version 20 software. Descriptive statistics such as percentages and
Sci. Technol. Arts Res. J., Oct-Dec 2015, 4(4): 113-119

frequency distribution was used to describe the nature and the characteristics of the data.

\section{RESULT}

Overall Mean for Productive and Reproductive Performance

The overall least squares means for AFS, AFC, $\mathrm{Cl}$ and LL in all crossbreed cows group in this study was estimated to be $24( \pm 4.16), 33.73( \pm 4.5), 14.64( \pm 2.2)$ and $11.96( \pm 2.5)$ months with range of $(16-40,25-54,11-21$ and 8-26 months) in which AFS and AFC were statistically significant difference $(p<0.05)$, respectively (Table 1$)$. However, the genetic groups of animals was observed in current investigation, the absence of significant association $(p>0.05)$ between the parameters like $\mathrm{Cl}$ and LL was seen.

The overall least square mean for NSPC was $1.35 \pm 0.42$ and showed statistically significant difference $(p<0.05)$. The overall least squares means for DP and MYPLL was estimated to be $81.3(2 \pm 18.7)$ and 3386.22 \pm 898 with range of $42-140$ days and 781.4-6418.6litters, respectively (Table 1) with statistically significant difference $(p<0.05)$. But, MYPLL was not statistically significant difference $(p>0.05)$ among genetic group of animals (Table 2 ).

Table 1: Over all mean reproductive and productive performance of crossbred dairy cows survey result

\begin{tabular}{lccc}
\hline Parameter & Over all means (N=215) & Minimum & Maximum \\
\hline AFS (By months) & $24 \pm 4.16$ & 16 & 40 \\
AFC (By months) & $33.73 \pm 4.5$ & 25 & 54 \\
Cl (By months) & $14.64 \pm 2.2$ & 11 & 21 \\
NSPC & $1.35 \pm 0.423$ & 1 & 3 \\
DP (By days) & $81.32 \pm 18.671$ & 42 & 140 \\
LL (By months) & $11.96 \pm 2.5$ & 8 & 26 \\
MYPLL (By liters) & $3386.22 \pm 898.719$ & 781.4 & 6418.6
\end{tabular}

AFS = Age at first service, $\mathbf{A F C}=$ Age at first calving, Cl= Calving interval, NSPC $=$ Number of service per conception, $\mathrm{DP}=$ Dry period, $\mathrm{LL}=$ Lactation length, $\mathrm{MYPL}=$ Milk yield per lactation length.

\section{Effects of Blood (Genetic) Level on Parity Number of Crossbred Cows}

A comparison has been made between the blood (genetic) levels with their parity numbers and highest percentage (29.8) was observed in $\mathrm{F}_{4}(87.5 \%)$ crossbred cows with a parity number $\leq 3$ and the result showed that there is statistically significant difference between the blood level and parity number $(p<0.05 ; \mathrm{OR}=12 ; 95 \%$ $\mathrm{Cl}=2.2-65.1)$. However, $\mathrm{F}_{5}(93.75 \%)$ and $\mathrm{F}_{3}(75 \%)$ in percentage of $11.6 \%$ and $14.4 \% 7.4 \%$, respectively were not statistically significant difference $(p>0.05)$ (Table 2$)$.

Table 2: Effects of Blood (Genetic) Level on Parity Number of Crossbred Cows

\begin{tabular}{|c|c|c|c|c|c|}
\hline Blood level & Parity Number & Frequencies (\%) & $p$-value & OR & $95 \% \mathrm{Cl}$ \\
\hline \multirow{3}{*}{$F_{5}(93.75 \%)$} & $\leq 3$ & $25(11.6)$ & 0.078 & 4.9 & $0.840-26.149$ \\
\hline & $4-5$ & $4(1.86)$ & 0.857 & 1.2 & $0.166-8.659$ \\
\hline & $\geq 5$ & $2(0.9)$ & - & & \\
\hline \multirow{2}{*}{ Total } & & $31(14.4)$ & & & \\
\hline & $\leq 3$ & $64(29.8)$ & 0.004 & 12.0 & $2.211-65.130$ \\
\hline \multirow[t]{2}{*}{$F_{4}(87.5 \%)$} & $4-5$ & $25(11.8)$ & 0.025 & 7.5 & $1.290-43.608$ \\
\hline & $\geq 5$ & $2(0.9)$ & & & \\
\hline \multirow[t]{2}{*}{ Total } & & $91(42.3)$ & & & \\
\hline & $\leq 3$ & $31(14.4)$ & 0.502 & 0.7 & $0.226-2.073$ \\
\hline \multirow[t]{2}{*}{$F_{3}(75 \%)$} & $4-5$ & $13(6.5)$ & 0.219 & 0.5 & $0.132-1.591$ \\
\hline & $\geq 5$ & $17(7.9)$ & & & \\
\hline Total & & $61(28.4)$ & & & \\
\hline \multirow{3}{*}{$F_{2}(50 \%)$} & $\leq 3$ & $16(7.4)$ & & & \\
\hline & $4-5$ & $10(4.7)$ & & & \\
\hline & $\geq 5$ & $6(2.8)$ & & & \\
\hline Total & & $32(14.9)$ & & & \\
\hline Ground Total & & 215(100) & & & \\
\hline
\end{tabular}


Zelalem Abera et alo,

\section{The Relationship between Parity and Blood Level}

\section{Age at First Calving}

The overall mean of age at first calving based on different genetic make-up (blood level) of crossbred was obtained as $34.6 \pm 5.37,33.7 \pm 4.1,33.36 \pm 4.6$ and 33.96 \pm 4.06 months in $50 \%\left(F_{2}\right), 75 \%\left(F_{3}\right), 87.5 \%\left(F_{4}\right)$ and $\geq 93.75 \% \quad\left(F_{5}\right)$ with statistically significant differences $(p>0.05)$, respectively. Cows were gives birth on average of every $13.2 \pm 1.45,14.42 \pm 1.7$ ), 15.3 \pm 2 .), 14.63 \pm ) months
Sci. Technol. Arts Res. J., Oct-Dec 2015, 4(4): 113-119

in $50 \%\left(F_{2}\right), 75 \%\left(F_{3}\right), 87.5 \%\left(F_{4}\right)$ and $\geq 93.75 \%\left(F_{5}\right)$, respectively (Table 3 ).

An average number of services required for each conception were $1.2 \pm 0.34,1.34 \pm 0.38,1.4 \pm 0.49$ and $1.3 \pm 0.35$ in $50 \%\left(F_{2}\right), 75 \%\left(F_{3}\right), 87.5 \%\left(F_{4}\right)$ and $\geq 93.75 \%$ $\left(F_{5}\right)$, respectively. Lactation length of the cows was ranged from $10.7 \pm 1.7,11.6 \pm 1.58,12.68 \pm 3.12$ and $11.89 \pm$ 2.16 in $50 \%\left(F_{2}\right), 75 \%\left(F_{3}\right), 87.5 \%\left(F_{4}\right)$ and $\geq 93.75 \%\left(F_{5}\right)$, respectively (Table 3 ).

Table 3: Mean Reproductive and lactation performance with different blood level of crossbred dairy cows

\begin{tabular}{llllll}
\hline \multirow{2}{*}{ Parameter } & \multicolumn{2}{l}{ Different blood level of crossbred } & \multirow{2}{*}{$\boldsymbol{p}$-value } \\
\cline { 2 - 5 } & $\mathbf{5 0} \% \mathbf{( F 2 )}$ & $\mathbf{7 5} \% \mathbf{( F 3 )}$ & $\mathbf{8 7 . 5} \% \mathbf{( F 4 )}$ & $\mathbf{2 9 3 . 7 5 \% ( F 5 )}$ & \\
\hline AFS & $25.16 \pm 5.24$ & $23.8 \pm 3.73$ & $23.7 \pm 4.08$ & $24.34 \pm 3.9$ & 0.016 \\
AFC & $34.6 \pm 5.37$ & $33.7 \pm 4.1$ & $33.36 \pm 4.6$ & $33.96 \pm 4.06$ & 0.008 \\
CI & $13.2 \pm 1.45$ & $14.42 \pm 1.78$ & $15.3 \pm 2.3$ & $14.63 \pm 2$ & 0.111 \\
NSPC & $1.2 \pm 0.34$ & $1.34 \pm 0.38$ & $1.4 \pm 0.49$ & $1.3 \pm 0.35$ & 0.030 \\
DP (By day) & $75.5 \pm 22.7$ & $82.68 \pm 15.7$ & $81.4 \pm 19$ & $84.4 \pm 17.8$ & 0.020 \\
LL & $10.7 \pm 1.7$ & $11.6 \pm 1.58$ & $12.68 \pm 3.12$ & $11.89 \pm 2.16$ & 0.25 \\
MYPLL (By Litter) & $2520 \pm 842$ & $3467 \pm 773$ & $3579 \pm 842$ & $3554 \pm 867$ & 0.166 \\
\hline
\end{tabular}

AFS=Age at first service, $\mathrm{AFC}=\mathrm{Age}$ at first calving, $\mathrm{Cl}=$ Calving interval, NSPC=Number of service per conception, $\mathrm{DP}=$ Dry period, $\mathrm{LL}=$ Lactation length, MYPL=Milk yield per lactation length., $\mathrm{F}_{2}(50 \%)$ $=$ Pure Holstein- Friesian $x$ pure zebu, $F_{3}(75 \%)=$ Pure HF crosses with $F_{2}$ breed, $F_{4}(87.5 \%)=$ Pure HF crosses with $\mathrm{F}_{3}$ breed, $\mathrm{F}_{5}(93.75 \%)=$ Pure $\mathrm{HF}$ crosses with $\mathrm{F}_{4}$ breed.

\section{DISCUSSION}

Retrospective study was conducted from 2008-2014 recorded data in Ada'a district, Debre Zeit town of Ethiopia. Effect of breed based on genetic level on reproductive and lactation performance of different genetic groups of crossbreed dairy cows are shown in (Table 3).

The overall least squares means for AFS, AFC, $\mathrm{Cl}$ and LL in all crossbreed cows group in this study was estimated to be $24 \pm 4.16,33.73 \pm 4.5,14.64 \pm 2.2$ and 11.96 \pm 2.5 months with range of $(16-40,25-54,11-21$ and 8-26 months), respectively (Table 2). The lowest mean of AFS 23.7 \pm 4.08 months was recorded in $\mathrm{F}_{4}$ and the highest AFS $25.16 \pm 5.24$ months was recorded in $\mathrm{F}_{4}$ genetic groups and the overall mean of AFS in this study was $24 \pm 4.16$ months. The study revealed that, there is statistically significant difference $(p<0.05)$ between both the first two parameters (AFS and AFC) and the genetic groups of animals (Table 2). However, the genetic groups of animals was observed in current investigation, the absence of significant association $(p>0.05)$ between the parameters like $\mathrm{Cl}$ and $\mathrm{LL}$ was seen.

It has been shown in previous studies that wellnourished temperate heifer has the potential to conceive at 14-15 months of age (Hafez, 2000; Ibrahim and Zemmelink, 2000). Though the result of this study have not reached to the standard level of AFS, there is in agreement with previous means of $24.3 \pm 8.01$ and shorter than the mean of $36.8 \pm 0.8$ months reported by (Belay Duguma, 2012) and (Gebayehu et al., 2005) respectively. The result is also in a range of previous findings of 23.2 months and 25.6 months of age reported by (Nuraddis et al., 2011) in Gonder town (Mureda and Mukuriew, 2007) in Dire Dawa.

On the other hand the lowest mean AFC in this study was found $33.36 \pm 4.6$ months for $F_{4}$ and highest is
34.6 \pm 5.37 months for $F_{2}$ with statistical significant difference $(p<0.05)$ among groups and the overall mean in this study was $33.73 \pm 4.5$ months which slightly in agreement with the report of (Haile-mariam et al. 1993) and (Yifat et al., 2009) who reported 32.7 and 31.9 months, respectively. On the contrary, this finding was higher than 28.5 and 29.2 months of age as reported for crossbreeds of Jersey $\times$ Arsi and Friesian $\times$ Arsi, respectively, at Asella Livestock farm, Ethiopia (Negussie et al., 1998).

Out of total number of 215 crossbred cows involved in this study, from highest to lowest number of the $F_{4}$ $(87.5 \%), \quad F_{3}(75 \%), \quad F_{2} \quad(50 \%)$ and $F_{5}(93.75 \%)$ in percentage of $91(42.3 \%), 61(28.4 \%), 32(14.9 \%)$ and 31 $(14.4 \%)$ were studied to compare their parity number with their blood level, respectively. Of these highest percentage (29.8) was observed in $\mathrm{F}_{4}(87.5 \%)$ crossbred cows with a parity number $\leq 3$ and the result showed that there is statistically significant difference between the blood level and parity number $(p<0.05$; OR $=12 ; 95 \%$ $\mathrm{Cl}=2.2-65.1)$. The result indicated that, $\mathrm{F}_{4}(87.5 \%)$ crossbred cows with a parity number $\leq 3$ were more likely gives birth 12 times as compared to that of cows with $\geq 5$ parity number. However, $F_{5}(93.75 \%)$ and $F_{3}(75 \%)$ in percentage of $11.6 \%$ and $14.4 \% 7.4 \%$, respectively were not statistically significant difference $(p>0.05)$.

A comparison has been made between the blood (genetic) levels with their parity numbers and highest percentage (29.8) was observed in $F_{4}(87.5 \%)$ crossbred cows with a parity number $\leq 3$ and the result showed that there is statistically significant difference between the blood level and parity number $(p<0.05 ; \mathrm{OR}=12 ; 95 \%$ $\mathrm{Cl}=2.2-65.1)$. However, $\mathrm{F}_{5}(93.75 \%)$ and $\mathrm{F}_{3}(75 \%)$ in percentage of $11.6 \%, 14.4 \%$ and $7.4 \%$, respectively were not statistically significant difference $(p>0.05)$.

Age at First Calving: The overall mean of age at first calving based on different genetic make-up (blood level) 
Zelalem Abera et al.,

of crossbred was obtained as $34.6 \pm 5.37,33.7 \pm 4.1,33.36$ \pm 4.6 and $33.96 \pm 4.06$ months in $50 \%\left(F_{2}\right), 75 \%\left(F_{3}\right)$, $87.5 \%\left(F_{4}\right)$ and $\geq 93.75 \%\left(F_{5}\right)$, respectively. Comparison has been made between the age at first calving and crossbred in this study in which the result showed significant differences $(p>0.05)$ between the two parameters (Table 3 ).

Calving Interval: Different genetic make-up of crossbred cows in this study area was observed and the cows were giving calves on average of every $13.2 \pm 1.45,14.42 \pm 1.78$, $15.3 \pm 2.3,14.63 \pm 2$ months in $50 \%\left(F_{2}\right), 75 \%\left(F_{3}\right), 87.5 \%$ $\left(F_{4}\right)$ and $\geq 93.75 \%\left(F_{5}\right)$, respectively (Table 3$)$.

As the result indicated that the overall least squares means for $\mathrm{Cl}$ in this study was $14.64 \pm 2.2$ across all genetic groups with no statistically significant difference ( $p>0.05$ ) among groups. The overall mean calving interval observed in the present study was shorter than 18.4 months and $21.36 \pm 3.84$ months as the findings of previous studies (Shiferaw et al., 2003) and (Belay, 2012) respectively and also shorter than 17.8 months for Boran $\mathrm{x}$ Holstein- Friesian $F_{1}$ crossbred dairy cows reported in Abernosa Ranch (Ababu et al., 2006). On the other hand the overall mean value in this study was higher than 12.4 months and 13.06 months reported by (Hunduma, 2012) and (Sena et al., 2014), respectively while it slightly in agreement with $13.4 \pm 5.1$ months previous study (Nibret, 2012).

Number of Service per Conception (NSPC): depends largely on the breeding system used. It is higher under uncontrolled natural breeding than artificial insemination (Gabriel et al., 1983). More than two number of service per conception should be considered as poor (Mukassa and Mugrewa, 1989). An effort was also made to detect NSPC during this study and the average number of services required for each conception of these crossbred cows with different genetic make-up was $1.2 \pm 0.34$, $1.34 \pm 0.38,1.4 \pm 0.49$ and $1.3 \pm 0.35$ in $50 \%\left(F_{2}\right), 75 \%\left(F_{3}\right)$, $87.5 \%\left(F_{4}\right)$ and $\geq 93.75 \%\left(F_{5}\right)$, respectively (Table 2$)$. As the result indicated, the lowest mean value of NSPC $(1.2 \pm 0.34)$ was in $F_{2}$ genetic group while the largest $(1.4 \pm 0.49)$ was recorded in $F_{4}$ genetic groups with statistically significant difference $(p<0.05)$ among groups.

The overall least squire mean across all genetic groups for number of service per conception revealed in the present study was $1.35 \pm 0.423$ which is closely to 1.3 as reported for crossbred cows in Gondar city of Ethiopia (Nibret, 2012). Overall mean value for NSPC in presented study was lower than 1.52 from Assela town of Oromia region of Ethiopia (Hunduma, 2012), 1.67 reported in mid Rift valley of Ethiopia (Yifat et a.,l 2009), 1.7 reported by (Lobago et al., 2006) in the highlands of Ethiopia, 1.8 for crossbred cows reported by (Tadesse et al., 2010) and 2.0 as reported for cows at Asella Livestock farm (Negussie et al., 1998).

Lactation Length: An attempt has also been made to observe the lactation length of the cows in last 2008-2014 (6years) and ranged from 10.7 $\pm 1.7,11.6 \pm 1.58$, $12.68 \pm 3.12$ and $11.89 \pm 2.16$ in $50 \%\left(F_{2}\right), 75 \%\left(F_{3}\right), 87.5 \%$ $\left(F_{4}\right)$ and $\geq 93.75 \%\left(F_{5}\right)$, respectively (Table 2$)$. The overall least squire mean lactation length for all genetic group in this study was $11.96 \pm 2.5$ months with the absence of statistically significant difference $(p>0.05)$ among genetic groups. Since lactation length of 10 months is commonly
Sci. Technol. Arts Res. J., Oct-Dec 2015, 4(4): 113-119

accepted as a standard. $50 \%\left(\mathrm{~F}_{2}\right)$ crossbred cows showed shorter calving interval $(10.7 \pm 1.7$ months) than $87.5 \%\left(F_{4}\right)$ crossbred cows (12.68 \pm 3.12 months).

However, the overall mean value of lactation length observed in the present study is markedly longer than 9.1(months) and 10.1 months reported by (Sena et al., 2014) and (Zelalem Yilma, 1999) respectively. And Current finding is similar with 11.7 months reported by (Adebabay, 2009). However, as a "rule of thumb" provision of recommended amount of roughage and concentrate can improve the milk production of cattle (Abegunawardana et al., 1997). On the other hand, the finding of age at first calving in the present study was shorter than 40.6 months as reported by (Shiferaw et al. 2003) for crossbreed dairy heifers in different dairy production system in central highland of Ethiopia.

Dry Period: The overall least squares means for DP in all crossbreed cows was estimated to be $81.3(2 \pm 18.7)$ with range of 42-140 days (Table 1 ) with statistically significant difference $(p<0.05)$ between DP and among the genetic groups of animals (Table 2). On the other hand the lowest mean value for dry period was $75.5 \pm 22$ days in $F_{2}$ than others with statistically significant difference $(p<0.05)$ among genetic groups. The result of overall mean value for dry period observed in this study was shorter than 97.2 days for crossbreed and 141days for indigenous breeds reported by (Ali et al., 2000) in Pakistan small holder dairy farms.

Milk Yield Per Lactation: During this study, the overall least squire mean for MYPL in all genetic group during this study were $3386.22 \pm 898.719$ litters with the absence of statistically significant difference $(p>0.05)$ among genetic groups. Comparatively it was lower than 5152, 5905 and 4791 litters as previously reported by (Jairath, 1995) HF breed cows in Canada and (Makuza and McDaniel, 1996) HF breed in Zimbabwe, respectively. The result of this finding also lower than 3710litters reported by (Tadesse, 2010) in Oromia central highland of Ethiopia. In the contrary the result was greater than 2757.3 and 1508 liters (Sena et al., 2014) and (Adebabay, 2009), respectively.

\section{CONCLUSION}

An ultimate goal in each herd should have lower calving interval, decreased number of services per conception, early calving, short dry period and increasing milk yield thereby increasing herd production. The result of the study revealed that the $F_{4}$ genetic group was shortest age at first service and age at first calving. It also high in lactation length and milk yield per lactation than others cows with different blood level. While the improved genetic level greater than $\mathrm{F}_{4}$ was less performed since their genetic make-up was close to pure breeding which difficult in the tropical temperature and susceptible for disease. On the other hand $F_{2}$ genetic group was short calving interval, low number of service per conception and short dry period.

In this study area, the obtained result was found to be good. Accessibility of enough land, controlled prevalent diseases, using improved level and proper breeding management such as accurate heat detection and timely insemination might have contributed considerably to early age at $1^{\text {st }}$ service and age at $1^{\text {st }}$ calving, short calving interval, long lactation length, and moderate milk production. Though the farm has enough access of land 
Zelalem Abera et alo,

and water, there was shortage of feed during dry seasons and also the farm only improving breeding for Borana with Holstein- Friesian breeds. Based on the above conclusion the following recommendations will forwarded:

$>$ The farm should be improve the livestock crop production

$>$ The farm should also practice different type of exotic breeds with different type of local breed.

$>$ It is possible to improve the reproductive and productive performance of dairy cows by better management practices, improved nutrition and use of new reproductive technology.

\section{Conflict of Interests} exist.

All authors have declared that no competing interests

\section{Acknowledgements}

We are very much grateful to the inhabitants of all staff members of Wollega University, College of Medical and Health Science, School of Veterinary for provision of materials and necessary supports during our work. I would like to express my deep appreciation and thanks to the Ethiopian meat and dairy industry development institute specially Dr. Karanfil Olga for permission to give all information and available data records.

\section{REFERENCES}

Ababu, C., Galina, S., Duchateou, A. and Navarro, R. (2006). Fertility trial in zebu cattle after a natural or controlled estrus with PGF2 $\alpha$ : comparing natural mating with Al. Theriogenology 23: 4-21.

Abegunawardana, H. (2002). Reproduction and Obstetrics in the Farm Animals (2nd edition). University of Perdeniya, Sri Lanka. Naresa Press, Colombo, Sri Lanka, 1:1-13.

Adebabay, K. (2009). Characterization of milk production systems, marketing and on-farm evaluation of the effect of feed supplementation on milk yield and milk composition of cows at Bure districts, Ethiopia, M.S. thesis, Bahir Dar University, Bahir Dar, Ethiopia. Pp: 14.

Ali, M., Khan, N., Rashid, M. and Khatun, I. (2000). Comparative performance study on the crossbreed and indigenous cow under small holder dairy farming. Pakistan Journal of Biological Sciences 3:795-798.

Aynalem, H., Joshi, K., Workneh, A., Azage, T. and Singh, A. (2009). Genetic evaluation of Boran cattle and their crosses with Holstein Friesian in central Ethiopia: milk production traits. Animal 3(4):486-493.

Belay, D., Yisehak, K. and Janssens, G. (2012). Productive and Reproductive Performance of Zebu X HolsteinFriesian Crossbred Dairy Cows in Jimma Town, Oromia, Ethiopia. Global Veterinarian 8: 67-72.

Bonnet, C. (2011). Identification of reproductive problems and economic consequences. In: Proceedings of National Invitational Dairy Cattle Reproduction Workshop, April 13-15, Louisville, KY (ed. Eastwood). Extension Committee on Policy (ECOP), Science and Education Administration, US Department of Agriculture, Washington, DC.

Central Statistical Authority (CSN), (2012). Federal democratic republic of Ethiopia, central statics agency, agricultural sample survey: report of livestock and livestock characteristics. Vol. 2 Addis Ababa, Ethiopia.
Sci. Technol. Arts Res. J., Oct-Dec 2015, 4(4): 113-119

Damron, S. (2006). Applied animal nutrition, feeds and feeding, 3rd ed. United States of America, Pp: 136

Ehui, S. (2000). A review of the contribution of livestock to food security, poverty alleviation and environmental sustainability in sub-Saharan Africa. Livestock production and the environment-implications for sustainable livelihoods. Proceedings of 7 th annual conference of Ethiopian Society of Animal Production (ESAP), held in Addis Ababa, Ethiopia.

Food and Agriculture Organization of the United Nations (FAO). (2009). Crop Diversification and Marketing Development Project, Interim Report. Addis Ababa, Ethiopia.

Forman, S.F., Belton, G., Evans, D., Francois, B., Murray, J.L., Sheesley, G., Vandersmissen, D.A. and Yoshimura, S. (2009). Moving towards the global control of foot and mouth disease: an opportunity for donors. Health Programmes in Developing Countries. Food and Agricultural Organization Expert Consultation, Rome. Revue scientifique et technique (International Office of Epizootics) 28(3): 883-896.

Gabriel, K., John, M., Trail, Y., Kurtu, W., Frank, A. and Jeffrey, D. (1983). Crossbred dairy cattle productivity in Arsi Region, Ethiopia. ILCA Research Report No. 11.

Gebeyehu, G., Asmare, A. and Asseged, B. (2005). Reproductive performances of Fogera cattle and their Friesian crosses in Andassa ranch, Northwestern Ethiopia, Livestock Research for Rural Development 17: 131.

Hafez, E. and Hafez, B. (2000): Reproduction in Farm Animals (7th edition). Lea and Febiger, Philadelphia, USA.

Haile-mariam, M., Banjaw, K., Gebremeskel, J. and Ketema, T. (1993). Productivity of Boran Cattle and their Friesian crosses at Abernossa Ranch, Ethiopia. I. Reproductive performance and prevailing mortality. Tropical Animal Health and Production 25: 239-248.

Hunduma, D. (2012). Reproductive performance of crossbred dairy cows under smallholder condition in Ethiopia. International Journal of Livestock Production 3: 25-28.

Ibrahim, M. and Zemmelink, G. (2000). A comparative evaluation of integrated farm models with the village situation in the Forest-Garden area of Kandy, Sri Lanka. Asian -Australasian Journal of Animal Sciences 13(1): 5359.

Jairath, J., Hayes, J. and Cue, R. (1995). Correlation between first lactation and life time performance traits of Canadian Holsteins. Jornal of Dairy Science 78:438-448.

Kumar, A., Lavania, G.S. and Lwthwal, S.S. (1991). Variations in conception rate of crossbred cattle. Asian Journal of Dairy Research 10(2): 69-72.

Kiwuwa, H., Trail, M., Kurtu, M., Worku, G., Anderson, F. and Durkin, J. (1983). Crossbred Production dairy cattle productivity in Arsi region, Ethiopia (Research report No. 11, ILCA, Addis Ababa, Ethiopia), Pp: 1-29.

Lobago, F., Bekana, M. and Gustafsson, H. (2006). Reproductive performances of dairy cows in smallholder production system in Selalle, central Ethiopia. Tropical Animal Health and Production 38: 333-342.

Madalena, E., Lemos, M., Teodoro, L., Barbosa, T. and Monteiro, N. (1990). Dairy production and reproduction in Holstein-Friesian and Guzera crosses. Journal of Dairy Science 73: 1872-1886. 


\section{Zelalem Abera et al.,}

Makuza, S. and McDaniel, B. (1996). Effect on day dry, previous days open and current days open on milk yields of cows. Jornal of Dairy Science 79:702-709.

MoA, (2006). Ministry of Agriculture and Rural Development, the Status of Animal Health Services in Ethiopia. Addis Ababa, Ethiopia.

Mukasa-Mugerewa, E, (1991). A review of reproductive performance of female Bos indicus (Zebu) cattle, International Livestock Centre for Africa (ILCA), monograph, Addis Ababa, Ethiopia. http://www.ilri.org/InfoServ/Webpub/Fulldocs/X5442e/x54 $\underline{42 \mathrm{e} 00 . \mathrm{htm}}$

Mureda, E. and Mekuriaw, Z. (2007). Reproductive performance of crossbred dairy cows in Eastern Lowlands of Ethiopia. Livestock Research for Rural Development 19 (161).

Nagvi, H. and Sejian, S. (2011): Bioclimates and Livestock, In: World Animal Science B5 Bioclimatology and the Adaptation of Livestock, H.D. Johnson, (Ed.), 3-16, Elsevier Science, ISBN 978-044-4426-90-1, Amsterdam, The Netherlands.

Negussie, E., Brannang, E., Banjaw, K. and Rottmann, U. (1998). Reproductive performance of dairy cattle at Assella livestock farm. Arsi. Ethiopia. I: Indigenous cows versus their $F_{1}$ crosses. Journal of Animal Breeding and Genetics 115: 267-280.

Nibret, M. (2012). Study on Reproductive Performance of Crossbred Dairy Cows under Small Holder Conditions in and Around Gondar, North Western Ethiopia. Journal of Reproduction and Infertility 3: 38-41.

Nuraddis, I., Shebir, A. and Shiferaw, M. (2011). Assesment of Reproductive Performance of Crossbred Cattle (Holstein Friesian X Zebu) in Gondar Town. Global Veterinaria 6(6): 561-566.

Perry, B.D., Randolph, T.F., Ashley, S., Chimedza, R., Forman, T., Morrison, J., Poulton, C., Sibanda, L., Stevens, C., Tebele, N., Yngstrom, I. (2003). The impact
Sci. Technol. Arts Res. J., Oct-Dec 2015, 4(4): 113-119

and poverty reduction implications of foot and mouth disease control in South Africa with special reference to Zimbabwe", International Livestock Research Institute, Nairobi, Kenya, 152 pp. and CD-ROM.

Sena. T., Guesch, F., Adugnaw, A., Beletech, H. and Workalem, D. (2014). Department of Animal Science, Debre Tabor University, Debre tabor, Ethiopia. Journal of Biology, Agriculture and Health Care 4: 23-25.

Shiferaw, Y., Tenhagn, B., Bekana, M. and Kassa, T. (2003). Reproductive performance of crossbred Dairy cows in different production systems in the central Highlands of Ethiopia. Tropical Animal Health and Production 25: 551561.

Tadesse, M., Thiengtham, A., Pinyopummin, G. and Prasanpanich, T. (2010). Productive and reproductive performance of Holstein Friesian dairy cows in Ethiopia, Livestock Research for Rural Development 22 (2)

Upton, M. (2001). Trade in livestock and livestock products: International regulation and role for economic development. Food and Agriculture Organization, Livestock information and policy branch, AGAL, Livestock Policy Discussion Paper Number 6.

Yifat, D., Kelay, B., Bekana, M., Lobago, F., Gustafsson, H. and Kindahl, H. (2009). Study on reproductive performance of crossbred dairy cattle under smallholder conditions in and around Zeway, Ethiopia. Livestock Research for Rural Development 21(6):121-125.

Zegeye, Y. (2003). Challenges and opportunities of livestock marketing in Ethiopia. Proceedings of The 10 annual conference of Ethiopian Society of Animal Production (ESAP), 22-24 August 2002 held in Addis Ababa, Ethiopia, 7: 47-54.

Zelalem, Y. and Ledin, I. (1999). Milk production system, processing techniques and the role of milk and milk products on the small holder farms in central high lands of Ethiopia. M.Sc. Thesis. Swedish University of Agricultural Sciences, Uppsala. Pp: 15-16. 